\title{
Traces of Violence: Representing the Atrocities of War
}

\author{
Eamonn Carrabine, University of Essex, UK
}

\begin{abstract}
This paper explores the relationships between war and representation through the use of visual images, and takes a cue from the French cultural theorist Paul Virilio, who has written extensively on the militarisation of vision in ways that have yet to be fully recognised in criminology. It then outlines some of the disputes surrounding documentary photography, not least since one of the main factors driving the development of the medium was the desire to record warfare, before turning to recent efforts to reconfigure the violence of representation by focusing on what has been termed 'aftermath photography', where practitioners deliberately adopt an anti-reportage position, slowing down the image-making process and arriving well after the decisive moment. This more contemplative strategy challenges the oversimplification of much photojournalism and the paper concludes by reflecting on how military-turned-consumer technologies are structuring our everyday lives in more and more pervasive ways.
\end{abstract}

\section{Keywords}

criminology, photography, representation, Virilio, war

In the twenty years since Ruth Jamieson (1998) urged criminologists to study war in a more critical, sustained and systematic way three main approaches have developed in the discipline: one that examines war as a state crime (Green and Ward, 2004) and a second perspective characterising military operations as a form of transnational policing (Degenhardt, 2010), while a third regards war as a corporate crime (Ruggiero, 2008). Attempts have since been made to advance new conceptual inroads into the relationships between criminology and war at many different theoretical, methodological and empirical 
levels. ${ }^{1}$ In this paper I explore the relationships between visual images and armed conflict to forge connections with the emerging field of visual criminology (Brown and Carrabine, 2017) and complement the different perspectives advocated by Vicenzo Ruggiero and Sandra Walklate in this volume. In his earlier call for a 'new criminology of war' Ruggiero (2005:245-6) argues that attention must be given to questions of ideological legitimation, not least since war often possesses an 'aura of sacredness' and 'collective celebration', and advocates a closer scrutiny of the representational practices involved in the cultural crafting and containment of war. Acts of war inevitably unleash divisions and considerable effort is devoted to containing the 'disruptiveness of military violence - making wars potentially more intense cultural productions than any peace-time phase of life' (Keller, 2001:x). By focussing on the cultural dimension the suggestion is that this should constitute a fourth criminological approach to war, in ways that offers distinctive analytical gains, along the lines set out in Mann's historical sociology. For Mann (1993:9) it is the 'struggle to control ideological, economic, military, and political power' that provides the 'central drama in social development' and crucially 'all four are necessary to social existence and to each other'. Although I will be concentrating on cultural analysis (or the 'ideological' in Mann's framework) the overall point is that a comprehensive criminology of war should be alive to these four different, but overlapping, sources of social power.

I am especially concerned with the use of images as historical evidence, so as to think through the relationships between war and representation, and understood as cultural work: 'armed conflicts are shot through with signs, and the processes of signification are shot through with conflict; warfare is, among other things an aesthetic enterprise and art, among other things, a site of battle' (Keller, 2001:xiv, emphasis in original). A diverse range of pictorial material can be examined from a visual culture perspective, as Keller's account of 
the Crimean War makes clear, and such sources are best regarded as contested 'traces' enabling us to 'imagine' the past more creatively, not least since they record a 'point of view' and constitute forms of 'eyewitnessing' (Burke, 2001:13-14). Images engage dynamics of seeing and not seeing, and can draw attention to absence as much as presence, mediating reality and posing important questions over what lies beyond the frame. As such the focus of this paper is not simply images of war, or even a war of images, but rather war is understood to be fundamentally an 'image event' (Padiyar, Shaw and Simpson, 2017:2), where the means of representation have long been central to the logistics of warfare. This point is derived from the French cultural theorist Paul Virilio whose work addresses the significance of war, architecture, media, technology and perception in ways that have yet to be fully recognised in criminology. The paper begins by setting out Virilio's central arguments before discussing some of the diverse ways in which war has been represented by documentary photographers in their efforts to challenge the oversimplification of much photojournalism.

This paper takes part inspiration from the fact photographers have made significant bodies of work on war and have questioned the idea of a photograph bearing neutral witness to events. It also seeks to examine the dynamic of spectacle and surveillance, the mixing of means of communication with those of destruction, at the core of Virilio's penetrating critique of how technological innovations are transforming contemporary life. The role of war in modern technological development is a sustained theme is his work, as is the reconceptualization of the traditional 'theatre of war', where the conventional role of wartime media to disseminate propaganda directed at civilians is now accompanied by forms of representation targeted at combatants themselves. The first part sets outs Virilio's arguments in more detail, the second highlights some of the ongoing ethical dilemmas photographers face when they document 
political violence. The third and fourth parts discuss efforts to reconfigure the violence of representation before addressing how the world itself has been transformed into a target.

\section{Virilio, War and Representation}

In his provocative account of how military 'ways of seeing' have transformed social relations Virilio (1989:7-8, emphasis in original) insists that there is no war 'without representation' and that it 'can never break free from the magical spectacle because its very purpose is to produce that spectacle: to fell the enemy is not so much to capture as to "captivate" him, to instil the fear of death before he actually dies'. His distinctive claim is that alongside the 'war machine' there has always existed a 'watching machine', which is concerned with providing an accurate picture of the enemy's shape and size, so that while Virilio's historical sweep is vast he is especially concerned with how cinematic techniques have become integral to modern conflict. As he famously puts it 'War is cinema and cinema is war' (Virilio, 1989:34, emphasis in original), and so the starting point for his argument is the First World War, which as the first great military-industrial conflict also introduced new logics of perception. A little later he wrote:

The year 1914 not only saw the physical deportation of millions of men to the battlefields. With the apocalypse created by the deregulation of perception came a different kind of diaspora, the moment of panic when the mass of Americans and Europeans could no longer believe their eyes, when their faith in perception became slave to the technical sightline: in other words, the visual field was reduced to the line of a sighting device.

(Virilio, 1994a:13, emphasis in original) 
His overall argument is that there has been a 'progressive dematerialization of warfare', in which technologies increasingly replace human beings, machines replace warriors on the battlefield, reducing the soldier to 'a cog in a servomechanism' (Kellner, 1999:109).

These themes are present in some of Virilio's earliest writings, including a study of the massive concrete bunkers that the occupying German army constructed along the western and northern coast of France to prevent an allied invasion. Some 15,000 were built during World War Two along a defensive 'Atlantic Wall' and the sheer scale of their construction was a potent symbol of total warfare for Virilio, transforming Europe into an enormous fortress. Yet at the same time they seemed strangely anachronistic, and the destruction of European cities from aerial bombardment completely shattered the myth of impregnability in such defensive, frontier installations. From 1958 to 1965 he photographed these elaborate, sinister relics abandoned to the sand, sea and wind. An exhibition of the photos along with drawings, cartography, diagrams, documents and his own writings on them were later curated by Virilio in 1975-6 and published in translation as Bunker Archaeology (1994b). Although he is not well known for writing on the aesthetics of photography, the approach pioneered here 'reveals an unmistakeable rapport between the aesthetics of the photographic image and the topic that provokes the main sortie in Virilio's long interrogation of the technology of war' (Phillips, 2013:91). His photographs document the aftermath of conflict and they have been described as 'hauntingly sublime images of the now silent relics of war, set against the natural beauty of the Atlantic coast' (Leach, 1999:73). In this probing of what Virilio terms the 'aesthetics of disappearance' we can see a demonstration of how questions of visual culture are closely tied to important political questions in his work. 
Pivotal is the attention given to the militarisation of vision and modern warfare has long placed a premium on visuality, though in 'late modern war' it is 'virtualisation that drives both the execution and the endorsement of its violence' (Gregory, 2010:173). According to Virilio the critical significance of warfare to understanding human history is far too often overlooked. A theme he also explores in Speed and Politics, which presents a 'war model' of the evolution of the modern city organised around the need for defence and preparation for war as the key dynamic shaping social life. As such his central thesis that the militarization of urban and political space at large, and technological innovations in particular, produces an acceleration of communication that profoundly alters our experience of the world. The importance of these arguments in criminology have been recognised by Wall and Monaghan (2011:241) in their account of drone warfare, technological politics and 'cosmic control'. I will return to the centrality of aerial perspective in the final section, but it should be emphasised that aviation occupies a pivotal place in Virilio's analysis, as 'airborne vision' stands for the 'evolution from the sites of war as fields of perception to the operation of perception itself as techno-culture' (Kaplan, 2013:75).

Virilio's work provides fresh ways of understanding the relationships between war and representation, which we hope to open up in this 'debate and dialogue' section of the journal. If Ruggiero (this volume) uses literature to shed fresh light on the criminology of war and Walklate (this volume) deploys a gendered lens to blur the very nomos of the discipline then this paper takes a cue from Virilio by looking at the visual in and of itself. Of course, visuality is also a site of contestation and the next section explores some of the disputes surrounding documentary photography, not least since one of the main factors driving the development of the medium was the desire to record warfare. At their core is a deep suspicion of photographs that document political violence. It features in the writing of Allan 
Sekula, Martha Rosler, Susan Sontag and can be traced back to Walter Benjamin's (1934/1982) dire warnings on photography's ability to beautify suffering. What each thinker shares is the conviction that 'aestheticizing suffering is inherently both artistically and politically reactionary, a way of mistreating the subject and inviting passive consumption, narcissistic appropriation, condescension, or even sadism on the part of viewers' (Reinhardt, 2007:14). The central issue for these writers is the relationship between photographs and their subject matter. The force of their critiques has been profound, to the extent that by the early 1990s it would have been said that 'documentary had surely had its day, perishing with the liberal politics that had nourished it; and along with it, naïve ideas about humanitarian reform and the ability of visual representation to capture reality' (Stallabrass, 2013:12). By then the movement was charged with exploiting the other and the 'truth claims' debunked as stage managed fictions. Faced with this existential crisis the practice has since recast its older social and political obligations, as we will see in later sections.

\section{Photography and Suffering}

In a celebrated essay Sekula (1975/1982:102) declared that the 'ills of photography are the ills of aestheticism' as part of his broader critique of the medium. Consequently, it has become commonplace to insist that images of suffering no longer have the impact they once had, while the deep suspicions over how the camera aestheticizes all that it pictures remains influential. To take one example, Shields (2015) has collected together sixty-four glossy war photos were published on the front page of the New York Times from the invasions of Afghanistan in 2001 and Iraq in 2003 up to 2013. By arranging them thematically the intention is to underline how they reproduce and reinforce certain visual tropes that glamourize war. The accusation is that the newspaper does all it can to transform violence into beauty, which ultimately serves to imply that 'a chaotic world is under control' (Shields, 
2015:9). By deliberately aestheticizing their subjects, they anaesthetize the viewer and this relationship between aesthetics and politics lies at the heart of picturing war and has led to increasingly porous boundaries between fact and interpretation. In what follows I discuss some classic and contemporary photographers to highlight the ongoing dilemmas faced in the representation of trauma.

War is a major subject for photographers and World War II effaced the distinction between civilian and combatant to the extent that since then those caught up in the conflict have received as much attention as the soldiers themselves. Indeed, it is often said that the stream of horrific images from Vietnam provided normative criticism of the war. Robert Capa's statement that 'if your pictures aren't good enough, you're not close enough' (cited in Marien, 2003:303) has long been the credo of the war photographer rushing off to battle to capture the death and destruction. It was the Spanish Civil War (1936-39) that was the first to be covered by corps of professional photographers from the frontline and Capa's photograph of a Republican soldier 'shot' by his camera reputedly at the same time as bullets rip through his crumpling body is one of the defining images of the war.

Initially published in 1936 the image has been the subject of considerable controversy since the 1970s when doubts first began to be raised over the authenticity of the photograph, and these disputes get at the heart of 'fundamental questions about the nature and reliability of photographic truth' (Brothers, 1997:179). The very point of the picture is that it captures a real moment fortuitously, but it 'loses all value should the falling soldier turn out to have been performing for Capa's camera' (Sontag, 2003:49). In her account of how the Spanish Civil War was photographed Brothers (1997) has tracked the case against authenticity of the image and she ultimately sides with those who view the image as staged and providing no 
documentary record of any moment of death. Yet she goes on to wonder why this image has become iconic, arguing that 'the very divergence of this image from the experience of most twentieth-century wars is so weighted with cultural allusion that it cannot help but constitute an historical source replete with evidence of attitude, belief and resistance to the reality of change' (Brothers, 1997:183-4). In other words, the image continues to pose questions on not only on what counts as evidence, but how the full horror is tamed by the 'pathos of wellknown tropes of war' (Pollock, 2012:71). One telling response to these tropes among war photographers has been to capture the sense of underlying meaningless in those zones of appalling suffering around the world.

A leading figure responsible for producing some of the most memorable and instantly recognisable war photographs of the past fifty years is Don McCullin. Since the 1960s he has covered conflicts in Cyprus, the Congo, Vietnam, Biafra, Northern Ireland, Cambodia, Beirut and Iraq. Throughout his images record the murder, madness and torment in complex and graphic ways that remain unsurpassed. McCullin himself maintained strong misgivings over the efficacy of documenting political violence, titling his book of excruciating photographs from the Vietnam war Is Anyone Taking Any Notice? (1973), or The Destruction Business (1972) in the British edition. Today it is no longer possible to take such images as journalists and photographers are officially "embedded" in war zones and their activities tightly controlled, including signing contracts over when and where their images can be shown: 'basically being like somebody's dog who is being taken out to Central Park for a walk around with the collar on,' as he put it (in Ritchin, 2013:101). Under conditions of such censorship, and criticisms of photojournalism more generally, photographers like Susan Meiselas, James Nachtwey and Gilles Peress have established distinctive visual styles in their coverage of war-torn regions like Bosnia, Chechnya and Nicaragua, creating alternative 
perspectives to counter the glorification of war and its seductive excitement. Others, especially with the advent of digital photography, have explored the ambiguities posed by photographic fact and fiction, merging art and reportage, in ways that critically explore the nature of violent conflict, as we will see in the next two sections.

The relationship between photographer and suffering subject have become increasingly the subject of much debate in recent years. Yet photographs, as Linfield (2010:39, emphasis in original) notes, are especially 'good at making us see cruelty'. Because the camera always sees more than the photographer pictures of violence not only allow, but invite us to respond differently from the perpetrators of atrocity, even when the pictures are intended to humiliate their victims. Consequently, the viewing of such pictures is not necessarily an act of voyeuristic exploitation prolonging the harm, but can lead to a 'deeper understanding, of the cruelty involved' (Reinhardt, 2012:36). As she puts it, the 'very thing that critics have assailed photographs for not doing - explaining causation, process, relationships - is connected to the very thing they do so well: present us, to ourselves and each other, as bodily creatures' (Linfield, 2010:39, emphasis in original). It is significant that these arguments are developed in the specific case of pre-execution photos taken by jailers at the Tuol Sleng prison during the Khmer Rouge genocide. These pictures of prisoners about to be executed constitute a traumatic documentary record, but it was not one that Western journalists covered at the time of the slaughter, or for some time after. Some conflicts are staged for the media, but many are not and this raises the important issue of how issues come to public attention and shape collective memory.

\section{Documentary Fictions}


A common complaint levelled against visual documentary concerns all that it excludes from view. It is often the case, especially when atrocities takes place, that cameras are forbidden. One response to the lack of documents is to invent them, and this is a 'regular tactic in the face of dictatorship and censorship' (Stallabrass, 2013:18) so that the making of 'documentary fictions' has become a way of representing traumatic events where little evidence remains. One exponent of this approach is Walid Raad and his work as the Atlas Group - an imaginary collective producing mixed media projects on the civil war in Lebanon, from 1975 to 1991 . Over the last twenty-five years he has created work exploring the veracity of documents, commenting on archival impulses and the conventions of museum display, to explore the role of memory, manipulation and narrative in histories of conflict. The project exposes the limits of what is thinkable and sayable by attempting to answer the question The Atlas Group (2003/2006:179-180) posed in an interview: 'How do we represent traumatic events of collective historical dimensions when the very notion of experience is itself in question?'

An example of their use of counter-memory to address serious political issues is the installation My Neck is Thinner than a Hair: Engines (9 January 1987), 2001/2003, which explores the aftermath of car bombs in Beirut. During the Lebanese civil war some 245 car bombs were remotely detonated in major cities by various factions killing thousands of people, often the engine was the only part of the car left intact after the explosion and the force of the blast would hurtle them far from site. As a result mangled car engines could be found scattered over the cityscape and photographs of them became a common feature of newspaper coverage during the conflict. The work is composed of a grid of 100 framed inkjet prints each featuring a black and white press photograph on the left and an equal-sized piece of paper with handwritten notes and date stamps on the right (Figure 1) <Figure 1 near here>. 
The repetitive presentation of them in this manner has been read as a comment on the banality of violence during the war and is said to explore issues of authorship, authority and authenticity in the documenting of Lebanese history.

Rather than suppressing their fabricated character, other photographers turn it into a virtue and make this quality integral to the meaning of the work. One of the leading practitioners of the staged tableau photograph is the Canadian artist Jeff Wall. His startling image, constructed in 1992 titled 'Dead Troops Talk (A Vision After an Ambush of a Red Army Patrol near Moqor, Afghanistan, Winter 1986)', is an example of how his work explores the relationships between photography and pictorial narrative found in painting and cinema (Figure 2). <Figure 2 near here> The huge picture has been described as 'exemplary in its thoughtfulness and power', yet the 'anithesis of a document' as the 'ambush is a made-up event' (Sontag, 2003:111) and was constructed in the artist's studio using actors, props, and technicians to create the tableau. The image is displayed on a large light box, giving the photograph a further macabre presence and spectacular quality, where the dead soldiers appear to talk and joke with one another. The large scale scene references both nineteenth century history painting and the narrative techniques of cinema, while the use of a light box suggests the backlit, billboard advertisements that themselves have long exploited the factual look of photography with invented scenes of commodity spectacle.

Another highly influential French photographer Luc Delahaye has turned away from conventional reportage and pushed at the boundaries of documentary. In his ongoing "History" series, which began in 2001 , he creates large scale images in panoramic format from various war zones, which when printed are almost two and a half metres in length that are designed to be shown in galleries. Delahaye deliberately takes what are the archetypal, 
fleeting subjects of photojournalism, but represents them in the more formal, grand style of art photography to create a historical tableau. The images are disturbing, partly because they are so carefully composed - as in his Kabul Road (2001) (Figure 3) <Figure 3 near here> where a group of men pose with corpses in the centre of the picture, which exudes the gravitas of a classical painting - but also because they are so aesthetically seductive. As one commentator puts it:

Photography, it has been said, is the "new history painting". And Delahaye has acknowledged this, admitting, in effect, photography - even news photography is as fictional as painting, as full of artifice. He is also hinting that historical events today can be said to be run - far-fetched as this may seem - not only for profit but for the media. War itself is simply an event "fabricated to be photographed", albeit on a vast, inhuman and immoral scale.

(Badger, 2014:98)

I explore the implications of this last point in the next section, as it unwittingly echoes Virilio's arguments on the very nature of war and representation.

In Virilio's (1994b) study of the remains of wartime architecture in Bunker Archaeology he includes a section on an 'aesthetics of disappearance', which anticipates the recent interest in documenting the aftermath of war. Some of the most unsettling and moving images of conflict are those where the photographer has arrived only to find a place where something used to be: the evidence only of an absence. An example of the power of such an approach is McCullin's 'The Battlefields of the Somme, France' photographed in 2000 eighty-four years after one of the most deadliest episodes of the First World War, where some sixty thousand 
British soldiers were killed or wounded on the first day alone and would ultimately claim more than a million casualties on both sides. The scene has been described as follows:

\author{
McCullin's photograph of endless fields and overcast skies shows a landscape \\ that still seems haunted by the carnage of battle, with a road winding into the \\ distance that emphasises the sense of absence and loss. To this day, farmers \\ continue to uncover the bodies of the dead, as well as the shrapnel, bullets and \\ unexploded ordnance known as the 'iron harvest'.
}

(Baker and Mavlian, 2014:182-183)

This more retrospective work explores the after-effects of war and conflict, maintaining a critical perspective on the passing of time, has become influential in recent years.

\title{
Aerial Perspectives
}

In contrast to the logic of much photojournalism, which seeks to record the spectacle of conflict as it unfolds, there has been an effort to reconfigure the violence of representation by focusing on the traces of conflict in a 'more reserved, pictorially still depiction of its aftermath' (Carville, 2014:73). A leading exponent of this more artistic mode is the French photographer Sophie Ristelhueber who has paid particular attention to the ruins and traces left by war and the scars it leaves on the landscape. It has been said that her images have the dry, objective look of an insurance assessors report, in that they seem to be presented purely as evidence. But we are invited to 'to view them culturally as well as factually, and to use our imagination as well as our eyes' (Badger, 2014:156). Her approach developed from an early series of photographs of post-surgical scars on human bodies taken at a hospital in Paris, 
which were exhibited at such a large scale that they were transformed into landscapes. The series consists of large-scale close-ups of fresh surgical stitches, framing sections of human flesh that remain strangely anonymous and mysterious. Then later she started to go to areas of war and conflict and photograph scars of war left on the landscape. Her images are traces of history and conflict, which she calls 'details of the world', are like scars on a body, and they convey a similar story of wounds barely healed, recording the violence inflicted on the surface of the earth by the machinery of war.

Some contemporary photographers have deliberately taken an anti-reportage position, slowing down the image-making process and arriving well after the decisive moment. This more contemplative strategy can be found in Simon Norfolk's various studies of war and his efforts to challenge the oversimplification of much photojournalism. In his photographs of Afghanistan (Norfolk, 2002) there is a deliberate attempt to understand the country's long struggle with colonialism and his images deploy a distinctive pictorial style, that invokes late eighteenth century Western landscape painting and its portrayal of the decline of once great civilizations. In this way, 'the skeletons of bombed-out buildings are shown as romantic ruins on deserted plains' to make the critical point that it is because of the destruction of over thirty years of war 'this ancient and culturally rich region has been returned to a premodern state' (Cotton, 2015:172). This attention to the traces of time and how to visualize the complexity of human suffering is developed in his subsequent work. The failure of Western governments to intervene in the conflict in the former Yugoslavia is a theme explored in Norfolk's (2005) Bleed, which revisits the frozen landscapes of eastern Bosnia where thousands were massacred and the almost abstract images become powerful allegories for the secrets buried beneath the ice. 
Both Norfolk and Ristelhuber often deploy an aerial perspective that recalls military reconnaissance photography and ever since the First World War such a "God's eye" view has become part of the iconic imagery of warfare. Building on Virilio's arguments Rey Chow (2006:31) suggests 'that in the age of bombing, the world has also been transformed into - is essentially conceived and grasped as - a target'. The centrality of the 'overhead image' to thinking through this concept of 'the world as target' has since been developed by Lisa Parks $(2013,2016)$ in a compelling account of the frequency with which such imagery now circulates in our global media culture. Their proliferation relates to a combination of factors, ranging from the commercialization of satellite and remote sensing technologies to the transformation of the Internet into a location-based web system, mobilising consumer subjects into 'militarized ways of being' (Kaplan, 2006:708). As she defines it:

the overhead image refers to image-data that has been acquired by instruments onboard aircraft or satellites, downlinked to earth stations, rendered by computer software, and, in some cases, composited for the purposes of representing, viewing, and analyzing particular sites or activities on earth. The production of the overhead image is made possible by a vast and largely invisible communication infrastructure, which, I would argue, undergirds the capacity to imagine the world as a target.

(Parks, 2013:197)

The notion of the world target, the use of overhead imagery and networks of remote platforms alerts us to how military-turned-consumer technologies are structuring our everyday lives in more abstract and increasingly pervasive ways. Many of these 
developments have been driven by an 'American military imaginary' where the 'virtualization of violence' is a key dynamic (Gregory, 2013:182).

According to Derek Gregory (2010) two modes of 'new war' have evolved since the end of the Cold War. One, is derived from the Revolution in Military Affairs (RMA) that transforms advanced state militaries (particularly in the global North) through an emphasis on strippeddown, highly specialised forces using the latest automated technology with unprecedented, robotic precision and the extensive use of private military contractors. The other is waged by non-state militias, insurgents and guerrilla forces (especially in the global South) and relies on light, often improvised weapons, targets its violence on civilians and is implicated in the illicit circuits of a 'shadow globalisation'. In practice, each seeps into the other and they overlap, frequently they are fought in the breaches of former empires and in the ruins of postcolonial states. They are staged 'disproportionately in the global South' and 'are the selective sites of military intervention by the global North', though it 'is often the nexus of South-North relations that provokes violence there in the first place' (Gregory, 2010:158). Although originating in the Soviet Union the RMA was promoted as the means by which American power could be globally secured.

Killing from ever increasing distances has long been a defining feature in the history of warfare. In todays 'drone wars' critics have ridiculed the remote piloting crews for merely 'commuting' to war, raising questions over the place of martial values in RMA warfare, while reducing military violence to something executed through and on a screen inculcates a 'PlayStation mentality' among perpetrators (Gregory, 2014:7-9). Yet to concentrate only on technological innovations obscures continuities with earlier uses of air power and explains why 'drones are doomed to fail in their current objective' (Satia, 2014:1). The British 
imperial state invented aerial counterinsurgency policing on the North West Frontier with Afghanistan and in Iraq (Mesopotamia) in the 1920s and for all the technical developments there are numerous similarities between then and now. Equally these 'seeing machines' generate shifting temporal geographies and it has been noted how they "collapse the near into the distant, and the present into the past and future' creating their own 'own "relative" geographies, folding several noncontiguous spaces around the globe into a single, distributed, "battlefield"” (Paglen, 2014:1). Our built environments are increasingly filled with machineto-machine seeing technologies, so that images no longer simply represent, but actively intervene in daily life in unseen ways. These ideas are clearly indebted to Virilio and return us to arguments introduced earlier in the paper. Likewise, Wall and Monahan (2011:250) have developed the concept of the 'drone stare' to describe a type of surveillance that 'abstracts targets from political, cultural, and geographical contexts, thereby reducing variation, difference, and noise that may impede action or introduce moral ambiguity.' The mixing of the means of communication with those of destruction has fundamentally altered the politics of warfare and empire.

\section{Conclusion}

Ever since the invention of photography in the nineteenth century, photographers (and various unmanned technologies) have covered almost every aspect of war and its aftermath. Photographs have been used to plan and conduct warfare, they have also been vital in securing support for armed conflict and have, on occasion, led to the loss of that support. Inevitably, I have only concentrated on a handful of photographs from the millions that have been produced and I have been especially concerned with some of the ways practitioners have depicted war in their efforts to counter the glamourization of violence. The First World War was the first instance where aerial photography was intensively used for strategic 
purposes. With airplane photography 'two globalizing mediums, one of transportation, and the other of communication, were united in the increasingly rationalized practice of warfare', while a 'third medium of destruction, long-range artillery, was quickly added to this instrumental collage, making possible bombardment - as well as image recording - at a great distance' (Sekula, 2016:34). These developments in military strategy speak to the dematerialization of warfare that has occurred over the last century, which is a central theme in Virilio's writing on the relationships between war and representation. He is especially critical of the 'pernicious industrialisation of vision' (Virilio, 1997:89) where machines increasingly see for us, ranging from camera to video through to satellite surveillance, and the ultimate degradation of human experience this entails. Such changes have not taken place all at once, but they do all entail the drive the gain heightened 'observational advantage' (Wall and Monahan, 2011:241) that increasingly loses any dependence on a human viewer combined with the gradual transformation of warfare to a question of data management.

A second theme addressed in this paper is the extent to which photography takes up the complex role of witness. Images of atrocity are 'deeply problematic' and are 'often accused of 're-victimisation, compassion fatigue, exploitation and the aestheticisation of suffering' (Lowe, 2014:212). The issue of how to resolve these dilemmas has been a central preoccupation of photographers and critics alike. As we have seen one important response has been to produce images that do not directly show the act of violence itself, but rather allude to it through exploring the topography of sites of conflicts. This new approach to representing conflict through its aftermath deliberately questions and avoids the simplistic visual language of mainstream media, while retaining an emotional and moral force. Such work of 'secondary witnessing' can bring 'recognitions of the present to bear not only on our understandings of the past, but also of the effects of the past on the present' (Apel, cited in 
Lowe, 2014:223). More generally these practitioners are using visual methods to explore abstract concepts like memorialisation, guilt or loss to reflect on the continuing repercussions of past conflict in the contemporary world. Although I have concentrated on cultural representation it should be clear that, following Mann (1993), this is one of four sources of power (the others being economic, military and political). Moreover, the four are closely entwined, overlapping and intersecting networks of social interaction, where the idea is that societies develop through conflict and cooperation.

The framework has been criticised for separating military and political power (Poggi, 2001), but for me this is a distinct advantage, as there are significant differences between 'organized violence, which has the distinctive organizational form of hierarchy, comradeship, and a distinctive mode of extracting compliance, lethal violence' and the 'kind of routinized deliberative assemblies, bureaucratic practices and legal codes which constitute the basis of states' (Mann and Haugaard, 2011:170). Arguably Virilio's decisive contribution is the recognition of the role of war in the organization of civilizations and politics, as well as to the production of wealth and technology. A force whose importance is often underestimated, and which a comprehensive criminology of war can begin to rectify. As Lea (2015:199) has noted, the work of the military is quite distinct from police work, but warfare combines 'both organised violence and the attempts to suppress the organised violence of the enemy' so that war is 'both "crime" and "criminal justice", merged into a single process'. Yet war is changing, and so is photography, but the relationship between them remains important. Photographers and their critics provide important insights into how war is evolving and how these 'changes evade or exploit norms of visibility' (Hariman, 2014:159) from which we have much yet to learn. 


\section{Acknowledgements}

This paper was presented at a seminar on Criminology and War held at Middlesex University in March 2017 and organised by Vincenzo Ruggiero. I am grateful to Vincenzo and Sandra Walklate for their comments on this presentation, as well as the two anonymous reviewers for their helpful comments on the initial version of the paper. All images are reproduced with the generous permission of the artists.

\section{Funding}

This work was supported by a Leverhulme Trust Major Research Fellowship, MRF-2014052.

\section{References}

Atlas Group (2003/2006) 'Let's be Honest, the Rain Helped', in Merewether, W. (ed.) The Archive, London: Whitechapel Gallery.pp.179-180.

Badger, G. (2014) The Genius of Photography, London: Quadrille.

Baker, S. and S. Mavlian (eds.) (2014) Conflict-Time-Photography, London: Tate.

Brothers, C. (1997) War and Photography: A Cultural History, London: Routledge.

Brown, M. and E. Carrabine (eds.) (2017) Routledge International Handbook of Visual

Criminology, London: Routledge.

Burke, P. (2001) Eyewitnessing: The Uses of Images as Historical Evidence, London: Reaktion Books.

Carville, J. (2014) 'The Violence of the Image: Conflict and Post-Conflict Photography in Northern Ireland', in Kennedy, L. and C. Patrick (eds.): The Violence of the Image:

Photography and Intenraional Conflict, London: IB Tauris. pp.60-77.

Chow, R. (2006) The Age of the World Target: Self-Referentiality in War, Theory, and Comparative Work, Durham, NC: Duke University Press. 
Cotton, C. (2015) The Photograph as Contemporary Art, London: Thames \& Hudson.

Degenhardt, T. (2010) 'Representing War as Punishment in the War on Terror', in International Journal of Criminology and Sociological Theory, 3:343-58.

Green, P. and T. Ward (2004) State Crime: Government, Violence and Corruption, London: Pluto Press.

Gregory, D. (2010) 'War and Peace', in Transactions of the Institute of British Geographers, 35: $154-186$.

Gregory, D. (2013) ‘American Military Imaginaries and Iraqi Cities’, in Mirzoeff, N. (ed.) The Visual Culture Reader, London: Routledge.pp.181-195.

Gregory, D. (2014) 'Drone Geographies’, in Radical Philosophy, 183 (Jan/Feb):7-19.

Hariman, R. (2014) 'Watching War Evolve: Photojournalism and New Forms of Violence', in Kennedy, L. and C. Patrick (eds.): The Violence of the Image: Photography and Intenraional Conflict, London: IB Tauris. Pp.139163.

Jamieson, R. (1998) 'Towards a Criminology of War in Europe', in Ruggiero, V., N. South and I. Taylor (eds.) The New European Criminology: Crime and Social Order in Europe. London: Routledge.pp.480-506.

Jamieson, R. (Ed.) (2014) The Criminology of War, Farnham, Surrey: Ashgate.

Kaplan, C. (2006) 'Precision Targets: GPs and the Militarization of US Consumer Identity' American Quarterly 58(3):693-713.

Kaplan, C. (2013) 'Desert Wars: Virilio and the Limits of "Genuine Knowledge”, in Armitage, J. and R. Bishop (eds.) Virilio and Visual Culture, Edinburgh: Edinburgh University Press.pp.69-85.

Keller, U. (2001) The Ultimate Spectacle: A Visual History of the Crimean War, London: Routledge. 
Kellner, D. (1999) 'Virilio, War, and Technology: Some Critical Reflections', in Theory, Culture and Society, 16(5-6):103-125.

Lea, J. (2015) 'Postscript: From the Criminalisation of War to the Militarisation of Crime Control', in Walklate, S. and R. McGarry (eds.) Criminology and War: Transgressing the Borders, London: Routledge.pp.198-211.

Leach, N. (1999) 'Virilio and Architecture', in Theory, Culture And Society, 16(5-6):71-84. Lowe, P. (2014): 'The Forensic Turn: Bearing Witness and the "Thingness" of the Photograph', in Kennedy, L. and C. Patrick (eds.): The Violence of the Image: Photography and Intenraional Conflict, London: IB Tauris. Pp.211-234.

Mann, M. (1993) The Sources of Social Power, volume II: The Rise of Classes and NationStates, 1760-1914. Cambridge: Cambridge University Press.Linfield, S. (2010) The Cruel Radiance, Chicago: University of Chicago Press.

Mann, M. and M. Haugaard (2011) 'Reflections on the Sources of Power', in Journal of Political Power, 4(2):169-178.

Marien, M. (2011) Photography: A Cultural History. London: Laurence King.

McGarry, R. and S. Walklate (eds.) (2016) The Palgrave Handbook of Criminology and War, London: Palgrave.

Nofolk, S. (2002) Afghanistan, Stockport: Dewi Lewis.

Norfolk, S. (2005) Bleed. Stockport: Dewi Lewis.

Padiyar, S., P. Shaw and P. Simpson (eds.) (2017) Visual Culture and the Revolutionary and Napoleonic Wars, London: Routledge.

Paglen, T. (2014) ‘Geographies of Photography'. Blogpost published on 11.04.2014available at https://www.fotomuseum.ch/en/explore/still-searching/articles/26980, accessed 07.27.2017. 
Parks, L. (2013) 'Zeroing In: Overhead Imagery, Infrastructure Ruins, and Datalands in Afghasnistan and Iraq', in Mirzoeff, N. (ed.) The Visual Culture Reader, London: Routledge.pp.196-206.

Parks, L. (2016) 'Drones, Vertical Mediation, and the Targeted Class', in Feminist Studies 42(1):227-235.

Phillips, J. (2013) 'Light Weapons/Darkroom Shadows: Photography, Cinema, War', in Armitage, J. and R. Bishop (eds.) Virilio and Visual Culture, Edinburgh: Edinburgh University Press.pp.86-101.

Poggi, G. (2001) Forms of Power, Cambridge: Polity.

Pollock G (2012) 'Photographing Atrocity: Becoming Iconic?', in Batchen G, M. Gidley, N. Miller and J. Prosser (eds) Picturing Atrocity: Photography in Crisis. London: Reaktion Books.pp.65-78.

Reinhardt, M. (2007) 'Picturing Violence: Aesthetics and the Anxiety of Critique', in Reinhardt, M., H. Edwards and E. Duganne (eds) Beautiful Suffering: Photography and the Traffic in Pain, Williamstown, MA: Williams College Museum of Art.

Reinhardt, M. (2012) 'Painful Photographs: From the Ethics of Spectatorship to Visual Politics’, in Grønstad, A. and H. Gustafsson (eds.) Ethics and Images of Pain, London: Routledge. Pp.33-56.

Ritchin, F. (2013) Bending the Frame: Photojournalism, Documentary, and the Citizen, New York: Aperture.

Ruggiero, V. (2005) 'Criminalizing War: Criminology as Ceasefire', in Social and Legal Studies, 14(2):239-257.

Ruggiero, V. (2008) 'Privatizing International Conflict: War as Corporate Crime', in Social Justics, 34:132-147.

Satia, P. (2014) 'Drones: A History from the British Middle East', in Humanity, 5(1):1-31. 
Sekula, A. (1975/1982) 'On the Invention of Photographic Meaning', in Burgin, V. (ed.)

Thinking Photography, Basingstoke: Palgrave.

Sekula, A. (2016) Photography against the Grain: Essays and Photo Works, 1973-1983, London: Mack.

Shields, D. (2015) War is Beautiful, New York: Powerhouse.

Sontag, S. (2003) Regarding the Pain of Others. London: Penguin.

Virilio, P. (1989) War and Cinema: The Logistics of Perception, London: Verso.

Virilio, P. (1994a) The Vision Machine, London: BFI.

Virilio, P. (1994b) Bunker Archaeology, New York: Princeton Architectural Press.

Virilio, P. (1997) Open Sky, London: Verso.

Wall, T. and T. Monahan (2011) 'Surveillance and Violence from Afar: The Politics of Drones and Liminal Security-scapes', in Theoretical Criminology, 15(3) 239254.

Walklate, S. and R. McGarry (eds.) (2015) Criminology and War: Transgressing the Borders, London: Routledge. 
Figure 1 Walid Raad/Atlas Group, My Neck is Thinner than a Hair: Engines (9 January 1987), 2001/2003.

Image to be supplied separately.

Credit line: @Walid Raad. Courtesy Paula Cooper Gallery, New York.

Figure 2 Jeff Wall Dead Troops Talk (a vision after an ambush of a Red Army patrol, near Moqor, Afghanistan, winter 1986), 1992, transparency in lightbox 229.0 x $417.0 \mathrm{~cm}$.

Image to be supplied separately.

Credit line: Courtesy of the artist.

Figure 3 Luc Delahaye Kabul Road, 2001, C-print, $111 \mathrm{~cm}$ x $241 \mathrm{~cm}$

Image to be supplied separately.

Credit line: Courtesy Luc Delahaye \& Galerie Nathalie Obadia.

\footnotetext{
${ }^{1}$ Three recently published edited collections give a sense of the current scope of the field: Jamieson's (2014) comprehensive reader contains a wide range of pieces that have helped to define it, Walklate and McGarry's (2015) collection of essays is a sustained attempt to place war within criminology, while contributors to their Handbook (McGarry and Walklate, 2016) address how the themes of crime, violence and victimisation in war challenge criminological orthodoxies and open up new directions in the discipline.
} 